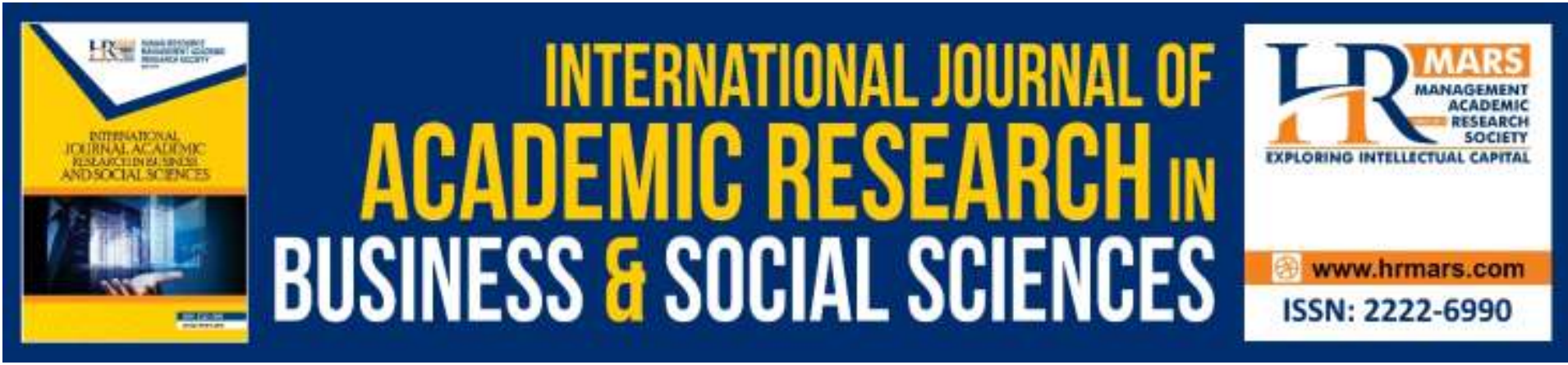

\title{
Ergonomic Risk Factors (ERF) and their Association with Musculoskeletal Disorders (MSDs) among Malaysian Construction Trade Workers: Concreters
}

Nor Suzila Binti Lop, Norazlin Mat Salleh, Fairiz Miza Yop Zain and Mohamad Tajudin Saidin

To Link this Article: http://dx.doi.org/10.6007/IJARBSS/v9-i9/6420

DOI: $10.6007 /$ IJARBSS/v9-i9/6420

Received: 18 July 2019, Revised: 16 August 2019, Accepted: 30 August 2019

Published Online: 20 September 2019

In-Text Citation: (Lop, Salleh, Zain, \& Saidin, 2019)

To Cite this Article: Lop, N. S. B., Salleh, N. M., Zain, F. M. Y., \& Saidin, M. T. (2019). Ergonomic Risk Factors (ERF) and their Association with Musculoskeletal Disorders (MSDs) among Malaysian Construction Trade Workers: Concreters. International Journal of Academic Research in Business and Social Sciences, 9(9), 1269-1282.

Copyright: (C) 2019 The Author(s)

Published by Human Resource Management Academic Research Society (www.hrmars.com)

This article is published under the Creative Commons Attribution (CC BY 4.0) license. Anyone may reproduce, distribute, translate and create derivative works of this article (for both commercial and non-commercial purposes), subject to full attribution to the original publication and authors. The full terms of this license may be seen at: http://creativecommons.org/licences/by/4.0/legalcode

\section{Vol. 9, No. 9, 2019, Pg. 1269 - 1282}




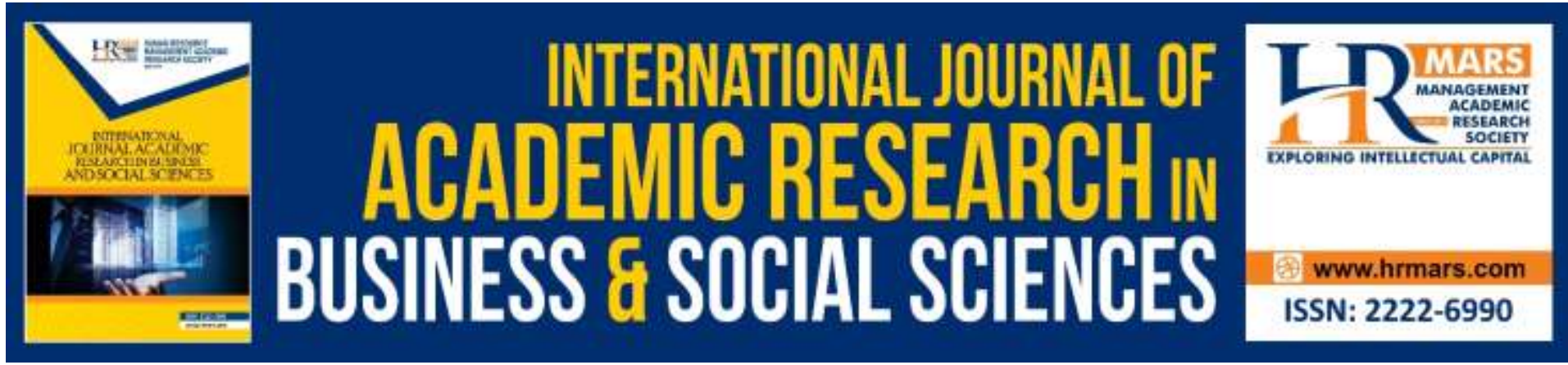

\title{
Ergonomic Risk Factors (ERF) and their Association with Musculoskeletal Disorders (MSDs) among Malaysian Construction Trade Workers: Concreters
}

\author{
Nor Suzila Binti Lop, Norazlin Mat Salleh, Fairiz Miza Yop Zain \\ and Mohamad Tajudin Saidin \\ Faculty of Architecture Planning and Surveying, Universiti Teknologi MARA, Perak Branch, \\ Seri Iskandar Campus, 32610 Seri Iskandar, Perak, Malaysia
}

\begin{abstract}
Construction sector is one of the highest risk industries contributing to the development of work-related musculoskeletal disorders. In general construction activities involve the composition of various construction trades, such as painting, plastering, concreting, paving and bricklaying. Different construction trades workers are exposed to risk factors depending on their job and task. Construction workers perform many physically demanding task including cleaning and preparing construction sites, digging trenches, operating power tools, bending machines, loading and unloading building materials and mixing and placing concrete. These activities expose workers to ergonomic risk factors (ERFs) such as awkward posture, repetitive motions, frequent heavy lifting and hand, arm and whole-body vibration which finally were affected the body muscle. Thus, this study was conducted among construction trade workers in particulars of concreters with the objective to identify the critical task or activities that affect the muscle of the body that is associated with the ERFs. The data for this research was collected via observation to the construction workers for the specific trades which involved concreters in Klang Valley. The finding of this research revealed that ERF (i.e. repetitive movement, awkward posture, and physical contact stress) associated with concreters' work is one of the major contributors of muscular disorders to the concrete body. These factors greatly affected the body muscle, nerves and tissue of the neck, shoulder, upper and lower back, upper and lower limbs and other parts of the body.
\end{abstract}

Keywords: Concreters, Ergonomic Risk Factors, Musculoskeletel Disoders, Work-Related Musculoskeletal Disorder. 


\section{Introduction}

The construction industry is a complex and unique industry where it has own characteristics and qualities that make it distinct from other industries. One of the characteristics of the construction industry is the involvement of many parties start from the inception stage until the building is handed over to the client. Due to this characteristic, the construction industry has been identified as one of the hazardous industries as it involves a variety of heavy construction activities (i.e. plastering, welding, roofing, installation of wall panel and etc.) that involve hazardous work with the use of heavy machinery. Furthermore, construction works by its nature has ergonomically hazardous, commonly requiring numerous awkward postures, heavy lifting and other forceful exertions (Schneider and Susi, 1994). When compared to other groups, construction workers show a higher risk of developing work-related musculoskeletal disorders (WMSD). These circumstances will contribute to short term injuries as well as long term injuries, especially to construction workers.

Construction workers from various trades are exposed to a significant risk of musculoskeletal injuries. It depends on the activities undertaken by construction workers as each of these activities involves varying physical body movements. According to Schneider, (2001), the physically demanding nature of the work, awkward and static postures, vibration, harsh outdoor environment, and related risk factors have contributed to strains and sprains type of work-related injury in construction. Construction activities performed by workers are usually repetitive and physically demanding. Execution of such tasks in awkward postures can strain their body parts and can result in fatigue, injuries or in severe cases permanent disability. These injuries typically occur due to awkward work posture while carrying out task as lifting loads (back and knee injuries) and working overhead (neck and shoulder injuries).

Work-related musculoskeletal disorder (WMSDs) which are problems of the musculoskeletal system, are significant problems that affect worker health and their productivity. These WMSDs affect the muscle, nerves and tissue of the neck, shoulder, back, upper and lower limbs. They can occur due to repetitive movement, inadequate working posture, over-exertion, physical contact with sharp edges, vibration and temperature. Body posture is an important consideration in the design of work method and workplace, because it affects the ability of workers to reach, hold, and use equipment and influences how long they can perform their job without adverse health effects, such as discomfort, fatigue, and musculoskeletal disorder. Musculoskeletal disorder can cause all the productivity by the construction workers become worst, they cannot do the work like a normal because of muscle pain, and their capability to maintain the works cannot be achieve because they only can stay maintain in a short time. The muscle endurance cannot stay for a longer time because the weakness of their muscle.

Thus, ergonomics is a significant factor in achieving and maintaining high levels of worker productivity. Execution of task by construction workers requires twisting body part such as shoulder joints, neck, back, and knees. In these situations, if the posture is such that body part is strained for a longer period of time, then it may cause fatigue, injuries, or in severe cases it may lead to permanent deformation.

According to a statistic report by the Department of occupational Safety and Health, Malaysia (DOSH) about occupational accidents for the category of death until October 2016, 163 of victims were reported by construction industry. According to the statistic report about the numbers of accidents by industry year 2015 conducted by SOCSO, 2,900 of cases were reported in construction industry. For the number of occupational diseases by causing agent 
reported in year 2015 by SOCSO (2016), 708 cases were reported in occupational musculoskeletal disorders. Recent studies and statistic have shown that the rates of musculoskeletal injuries and disorders among workers in the construction trades are much higher when compared to those working in other industries. In addition, data about occupational disease by private workers from the National Worker's Social Security Organization in Malaysia from 2002 until 2006 shows that from overall incidence rate there was 2.8 per 100,000 workers experience MSDs. Most of them are often suffering pain, numbness, tingling and swelling around their bodies. These worst MSDs pain and injuries may cause by manual handling of heavy material which including lifting, lowering, carrying, pulling, pushing and also forced to work overtime in long hours such as 12 hours shifts and six days a week (Santos et al., 2014). Therefore, this research aimed to identify the critical activities that affect the muscle of the body associated with the ERFs, in particular to the concreters.

\section{Literature Review \\ Overview of Ergonomic in Construction Industry}

Ergonomics, as defined by the Board of Certification for Professional Ergonomists (BCPE) is the ability of human body, human characteristics and human limitations that are relevant to design. Ergonomic design is the application of this body of knowledge to the design of machines, tools, systems, tasks, jobs, and environments for safe, comfortable and effective for human use (BCPE, 1993). The term ergonomics is received from the Greek word ergos meaning "work" and nomos meaning "natural laws of" or "study of" work (Te-Hsin \& Kleiner, 2001). While, Jaffar et al. (2011) defined ergonomics as the relationship between humans, machine systems, job design and the work environment.

Ergonomics is a science, it is a tight, user-centered approach to research and design. It is also a philosophy and a way of thinking. It is applied widely in areas such as aviation and other transport systems, sport, construction, education, public facilities, the home recreational equipment and facilities and in the workplace generally. In construction industry, ergonomics design is important to the construction workers as it give a comfortability to the worker to do their job, such as for concreter, bricklayer, plasterer, roofer, plumber, and other trades.

Besides, ergonomics is a broad science with wide variety of working conditions that can affect worker's comfort and health, including factors such as lighting, noise, temperature, vibration, heavy lifting, repetition motion, workstation design, tool design, machine design, chair design and footwear and others. Job design also gives a big impact with such factors such as shift work, breaks, and meal schedules. These factors can result in injuries or related problems may develop to musculoskeletal disorder (MSDs). MSDs or musculoskeletal disorders are injuries and disorders of the soft tissues (muscle, tendons, ligaments, joints, and cartilage) and nervous system. They can affect nearly all tissues, including the nerves and tendon sheaths, and most frequently involve the arms and back. These conditions will affect the health of construction workers and may adversely affect the workers' ability to perform their duties.

\section{Ergonomic Risk Factor (ERF) affecting MSDs among Construction Trades Workers Ergonomic Risk factors}

In most cases, risk factors related to work activities, actions or conditions that contribute to injury to the musculoskeletal and ergonomic systems make it more difficult to 
control. It can increase the probability that some individuals may develop a musculoskeletal disorder in the long-term period. The exposure to the risk factor shows an early warning that finally brings for more serious problems that can lead to serious injury. Besides, this long-term exposure to risk factor will decrease the value of life that might harmful to the health and wellbeing of the worker. Therefore, before any resolutions to the problems could be suggested, the understanding and awareness about the negative feature of ERF are critical and essential to be considered (Jaffar et al., 2011; Matarid, Sobh, \& Ahmed, 2018).

Before resolutions to the problems could be made, the understanding and awareness about the negative feature of ERF are critical and essential for consideration (Jaffar et al., 2011). There are several types of ERF that affect to the body muscle for instance repetition, awkward posture, force, contact stress, vibration, static loading and extreme temperature (OSHA, 2000). Exposure to ERF over a long period of time can develop into more serious problems such as symptoms and physical signs that can lead to more serious injuries namely musculoskeletal disorder (MSD). In the construction industry, each task carries different risks depending on the work to be performed. Therefore, it is crucial among the employers and workers to notify on how to decrease MSD injury risk related to the task performed through the awareness of ergonomic risk factors.

In reality, not all workers that exposed to risk factors will develop MSDs. For example, there two workers whose are exposed to the same combination of risk factor and in the same degree, respond to them in the same way because of a different person different body fit (Jaffar et al., 2011). Yet, these are common factors that may give effect to the MSDs in some combination and in some people. The Ergonomic Risk Factors (ERF) associated with the work task are discussed and listed in Table 1. 
TABLE 1. Ergonomic Risk Factors Associated with Work Task among the Construction Trade

\begin{tabular}{|c|c|c|c|}
\hline \multicolumn{4}{|c|}{ Worker } \\
\hline Risk Factors & Causes & Trade & $\begin{array}{l}\text { Muscle part } \\
\text { exposed to } \\
\text { MSDs }\end{array}$ \\
\hline $\begin{array}{l}\text { 1. Awkward } \\
\text { Postures }\end{array}$ & $\begin{array}{l}\text { Using awkward postures to work } \\
\text { and be in the same posture for a } \\
\text { long time. For example, } \\
\text { repetitive when kneeling, } \\
\text { squatting, wrist bend, twisting } \\
\text { while lifting, reaching material } \\
\text { above shoulder height. }\end{array}$ & $\begin{array}{l}\text { Metal worker cutting } \\
\text { down the metal bar in } \\
\text { awkward position } \\
\text { where he bends } 90^{\circ} \\
\text { and expose to } \\
\text { vibration by machine } \\
\text { he holding. }\end{array}$ & $\begin{array}{l}\text { Lower and } \\
\text { upper back, } \\
\text { knee, wrist, } \\
\text { thigh and } \\
\text { shoulder. }\end{array}$ \\
\hline 2. Force & $\begin{array}{l}\text { Exerting excessive force can } \\
\text { cause a variety of injuries. For } \\
\text { example, lifting heavy object, } \\
\text { pushing or pulling heavy load, } \\
\text { manually pouring materials or } \\
\text { maintaining control of } \\
\text { equipment or tools. }\end{array}$ & $\begin{array}{l}\text { A group of workers lift } \\
\text { up a huge timber } \\
\text { platform where can } \\
\text { expose to the } \\
\text { excessive force to } \\
\text { hand, shoulder and } \\
\text { back. It should be } \\
\text { done by lift it using } \\
\text { machineries. }\end{array}$ & $\begin{array}{l}\text { Wrist, lower } \\
\text { and upper } \\
\text { hand, } \\
\text { shoulder. }\end{array}$ \\
\hline
\end{tabular}

TABLE 1. continued

$\begin{array}{cccc}\text { Risk Factors } & \text { Causes } & \text { Trade } & \begin{array}{c}\text { Muscle part } \\ \text { exposed to MSDs }\end{array}\end{array}$

3. Repetitive Known as performing the The bricklayers will Lower and upper same task or repetitive. expose more to back, wrist, thigh For example, performing repetitive during and knee. the same movement laying bricks stage. continuously or They keep repeat the frequently for a long same movement until period. the wall is form.

\begin{tabular}{|c|c|c|c|}
\hline 4. Vibration & $\begin{array}{l}\text { It can affect the whole } \\
\text { body and hand-arm. If } \\
\text { vibration to hand-arm can } \\
\text { cause minor damage to } \\
\text { capillaries that carried } \\
\text { nutrient and make hand } \\
\text { difficult to control tools. }\end{array}$ & $\begin{array}{l}\text { Worker using machine } \\
\text { during the break up } \\
\text { the tarmacadam } \\
\text { exposes to vibration } \\
\text { to arm or even to the } \\
\text { whole body will }\end{array}$ & $\begin{array}{l}\text { Lower and upper } \\
\text { hand, lower and } \\
\text { upper back. }\end{array}$ \\
\hline
\end{tabular}




\begin{tabular}{|c|c|c|c|}
\hline & $\begin{array}{l}\text { While, it effects also can } \\
\text { damage body and will } \\
\text { increase the force. }\end{array}$ & $\begin{array}{l}\text { damage the soft } \\
\text { tissue. }\end{array}$ & \\
\hline 5. Static Loading & $\begin{array}{l}\text { Activity that position of } \\
\text { the worker need to hold } \\
\text { for extended period of } \\
\text { time. Thus, it can restrict } \\
\text { blood flow and damage } \\
\text { several muscles. }\end{array}$ & $\begin{array}{l}\text { The operator keeps } \\
\text { staying in the same } \\
\text { position for longer } \\
\text { period will caused } \\
\text { static loading on the } \\
\text { lower body. }\end{array}$ & $\begin{array}{l}\text { Wrist, shoulder and } \\
\text { upper back. }\end{array}$ \\
\hline 6. Contract Stress & $\begin{array}{l}\text { These activities localized } \\
\text { pressure into the body. } \\
\text { For example, pressing the } \\
\text { body or part of the body } \\
\text { like hand or sharp edges. } \\
\text { Additionally, using any } \\
\text { tools by hand for example } \\
\text { using hammer. }\end{array}$ & $\begin{array}{l}\text { Worker who always } \\
\text { holding small tools } \\
\text { and keep press into it } \\
\text { will expose to contract } \\
\text { stress. }\end{array}$ & Fingers, wrist \\
\hline $\begin{array}{l}\text { 7. Extreme } \\
\text { Temperature }\end{array}$ & $\begin{array}{l}\text { Extreme temperature can } \\
\text { be classified for both } \\
\text { extreme cold and hot } \\
\text { temperature. Many of } \\
\text { operation expose to } \\
\text { extreme temperature } \\
\text { caused worker more } \\
\text { force. }\end{array}$ & $\begin{array}{l}\text { Welder or worker } \\
\text { whose expose to high } \\
\text { temperature will face } \\
\text { extreme temperature. }\end{array}$ & $\begin{array}{l}\text { Whole muscle of the } \\
\text { body }\end{array}$ \\
\hline
\end{tabular}

Table 1 shows the different risk factor lead to different causes (Occupational Safety and Health Administration (OSHA, 2012). Sometimes, the risk factor also affected by the working environment too. All the risk factor will affect the worker in different part or different ways. However, all the risk factors are harmful to workers' bodies either it is minor or major injury. In some cases, the injury become chronic and the workers suffer a lot by this disorder.

\section{The Main Activities undertaken by concreter}

Concreter is a person who able to pour or works with concrete. Basically, a concreter apprentice is involved in pumping, spreading, vibrating, compacting, trowelling, finishing and curing concrete for buildings using hand tools or machine. Basically, a concreter needs to be physically fit because concrete work is one of the heavy works at construction site. A concreter also must be able to follow verbal instructions by the supervisor to avoid from any mistake happen during working and to avoid any accident happen. Table 2 presents the 
activities related to the concrete works. There are pumping of concrete, spreading concrete, vibrating concrete, compacting concrete, trowelling, finishing and curing the concrete.

Table 2. Activities Related to the Concreter

\begin{tabular}{lll}
\hline $\begin{array}{c}\text { Construction- } \\
\text { Related } \\
\text { Activities }\end{array}$ & Description of Task & Figure \\
\hline $\begin{array}{l}\text { Pumping } \\
\text { Concrete }\end{array}$ & $\begin{array}{c}\text { Pouring the concrete to the required area by } \\
\text { using a hose from pumping concrete }\end{array}$ \\
\hline
\end{tabular}

$\begin{array}{ll}\begin{array}{l}\text { Spreading } \\ \text { concrete }\end{array} & \text { Spread the fresh concrete to the position as } \\ \text { close as possible to finish level to facilitate in } \\ \text { screeding the concrete. }\end{array}$

$\begin{array}{ll}\text { Vibrating } & \quad \text { Vibrate the concrete using concrete vibrator } \\ \text { concrete } & \text { to minimize the surface void at the concrete. }\end{array}$

to minimize the surface void at the concrete.

\begin{tabular}{ll}
\hline $\begin{array}{l}\text { Compacting } \\
\text { Concrete }\end{array}$ & $\begin{array}{l}\text { Compact the concrete by using a vibrator to } \\
\text { make the concrete more dense, strong and } \\
\text { durable }\end{array}$
\end{tabular}

$\begin{array}{ll}\text { Trowelling } & \text { The concreter will smooth the concrete } \\ \text { Concrete } & \text { surface by using a steel or timber trowel }\end{array}$

\begin{tabular}{ll} 
& \\
\hline Finishing & Finishing concrete are likely same with the \\
troncrete & surface of concrete
\end{tabular}
Curing Concrete $\bullet$ Final stage is curing the concrete. To ensure that the concrete does not dry out prematurely, keep in moisture to build up strength of concrete
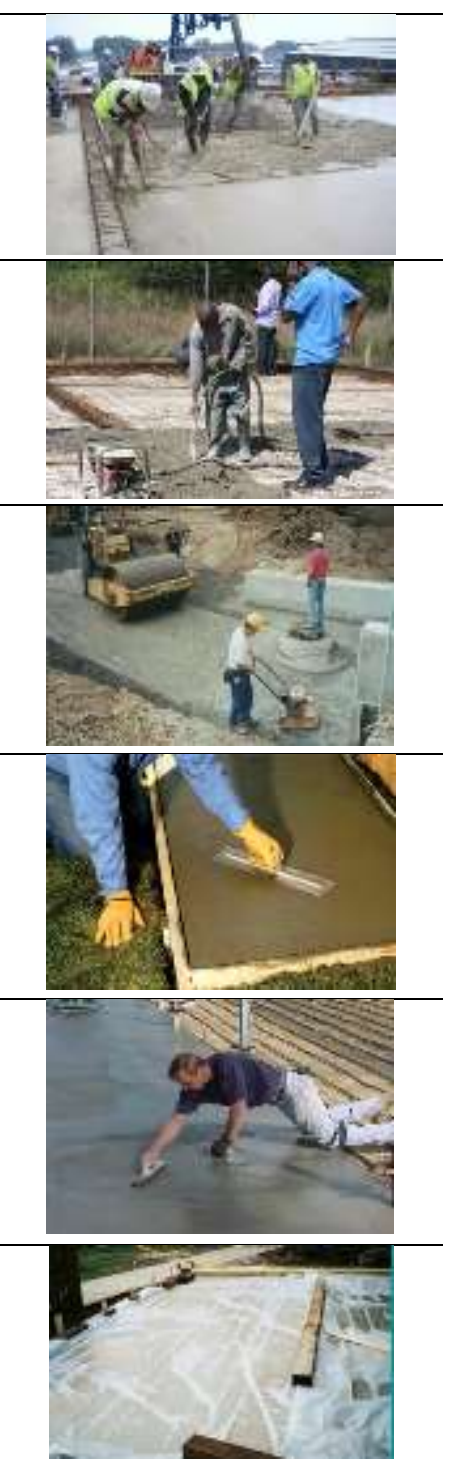
A concreter must be able to work as part of a team because if concreter work in team indirectly they can help each other, and there is no burden to each concreter and the risk to getting pain can be reduced. Other than that, a concreter must be able to work at any working conditions by wearing the protective clothing and mask because as we know at construction site, there is fully with the dust that can bring a problem to the workers respiratory, and make them difficult to perform their task. A concreter can be classified as important person in construction site, because most of the work need a concrete as a basis for their work such as concrete for slab, plastering wall, concrete staircase, flat roof and other work related to the concrete. Concreter is responsible to produce a concrete in a good quality. A concreter will use a full part of body during working such as neck, shoulder, upper arm, upper back, lower arm, lower back, wrist, buttock, knee, thigh and lower leg.

\section{Research Methodology}

Data collection is the utmost important stage in this study in order to achieve the desired objectives within the scope of work. This study was collected data by the observation on the activities of the trade workers (concreters) at construction site, case study in Klang Valley. Observational survey was used to collect the data on the critical task associated with the ERF undertaken amongst concreters. The observational survey would record in the tabulation format the behaviour of the respondents in order to determine which part of the body affected through the concreting activities (Lop et al., 2017; Tharim et al,. 2011; Sangakala, Ahmed, \& Pahi, 2016). The scope of research is limited to the skill workers involved in concreting works. The survey was conducted from February 2018 to April 2018. The construction workers of concreters from the construction projects was selected as the sample for the observation. The data collection from the observation then analysed. The data was presented in the form of tabulation to explain the results.

\section{Analysis and Discussion of Observation Findings: Critical Task Associated with the ERF Undertaken Amongst Concreters}

Based on Table 3, the main task in concreting works involved filtering the sand, lifting cement, mixing concrete, transport concrete to the location, pouring concrete, levelling concrete, and curing the concrete. These construction-related activities are closely related to ergonomic risk factors. Uncontrol ergonomic risk factors over a long period of time can cause injury to the body muscle. Ergonomics risk factors particularly related to the musculoskeletal disorders can be seen from each activity of concreting works.

Concreting works are arranged one after another until complete the structure to be construct. It normally started with the filtering the sand until process of curing concrete. All these activities involve an awkward posture and repetitive works to the construction workers. Results from the observations revealed that, mixing and transporting of the concrete are among the activities that contribute to the higher musculoskeletal disorders. It may due to the task that need to be carried out repetitively for a long period of time. These activities involved ergonomics risk such as repetitive body movement and awkward posture to some part of the body like manually lifting heavy materials, mixing the materials and placing the material (fresh concrete) to the location. The affected part of the body due to the ERF are lower and upper back of the body, shoulder, hand, wrist, and knee. As a result, the affected repetitively body movement will eventually cause damage to the muscles of the body. 
TABLE 3. Critical Task Associated with the ERF Undertaken Amongst Concreters

\begin{tabular}{|c|c|c|c|c|}
\hline $\begin{array}{l}\text { Construction- } \\
\text { Related } \\
\text { Activities }\end{array}$ & $\begin{array}{l}\text { Description of } \\
\text { Task/Activities }\end{array}$ & $\begin{array}{l}\text { Problematic } \\
\text { Work-Related } \\
\text { Activities }\end{array}$ & $\begin{array}{l}\text { Ergonomic Risk } \\
\text { Factors (ERFs) }\end{array}$ & Figure \\
\hline $\begin{array}{l}\text { Filtering the } \\
\text { sand }\end{array}$ & $\begin{array}{l}\text { Filtering the } \\
\text { coarse sand for } \\
\text { fine sand }\end{array}$ & $\begin{array}{l}\text { The major part } \\
\text { exposed to MSDs } \\
\text { is shoulder, } \\
\text { upper and lower } \\
\text { hand, wrist and } \\
\text { upper back of } \\
\text { body }\end{array}$ & $\begin{array}{l}\text { - Repetition } \\
\text { movement } \\
\text { Continuously do } \\
\text { the same activity } \\
\text { which is filtering } \\
\text { the sand }\end{array}$ & \\
\hline
\end{tabular}

\begin{tabular}{|c|c|c|c|c|}
\hline $\begin{array}{l}\text { Lifting } \\
\text { cement bag }\end{array}$ & $\begin{array}{l}\text { Lifting cement } \\
\text { bag from the } \\
\text { storage area and } \\
\text { carried it to } \\
\text { concrete mixer }\end{array}$ & $\begin{array}{l}\text { The major part } \\
\text { exposed to MSDs } \\
\text { is shoulder, } \\
\text { upper and lower } \\
\text { hand, wrist, knee } \\
\text { and upper and } \\
\text { lower back of } \\
\text { body }\end{array}$ & $\begin{array}{l}\text { - } \frac{\text { Awkward }}{\text { posture }} \\
\text { Bending forward } \\
\text { and downward } \\
\text { while lifting the } \\
\text { cement }\end{array}$ & 52 \\
\hline
\end{tabular}

Carrying the $\begin{aligned} & \text { Carried the The major part - Forceful Exertion } \\ & \text { cement bag to exposed to MSDs Carrying a cement } \\ & \text { location } \\ & \text { (concrete mixer) }\end{aligned}$
is shoulder, bag from one place
upper and lower to another place
hand, upper and
lower back of
body

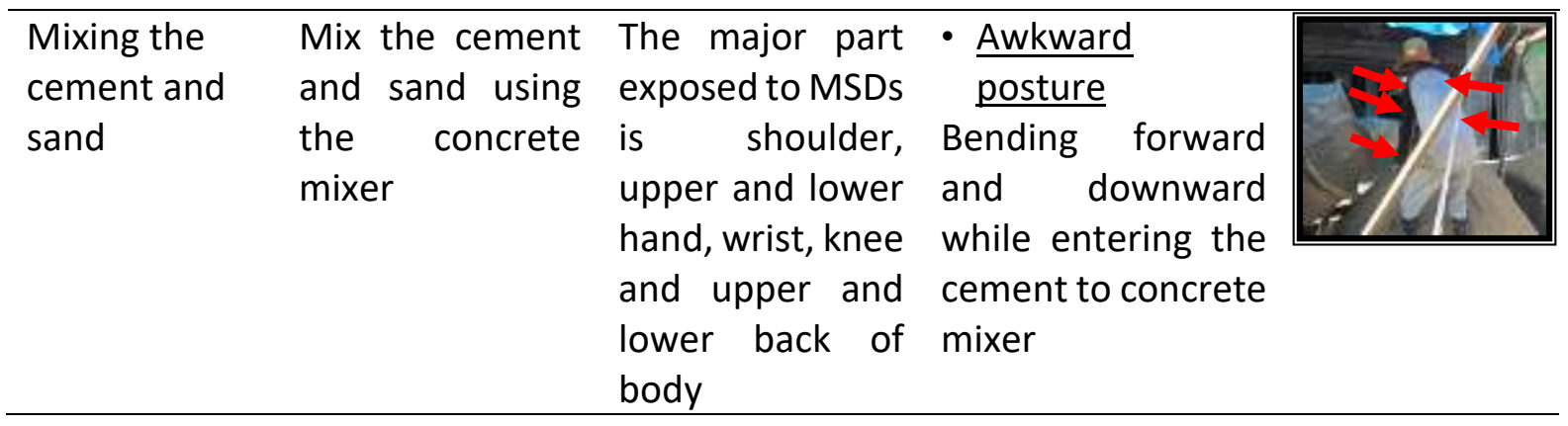




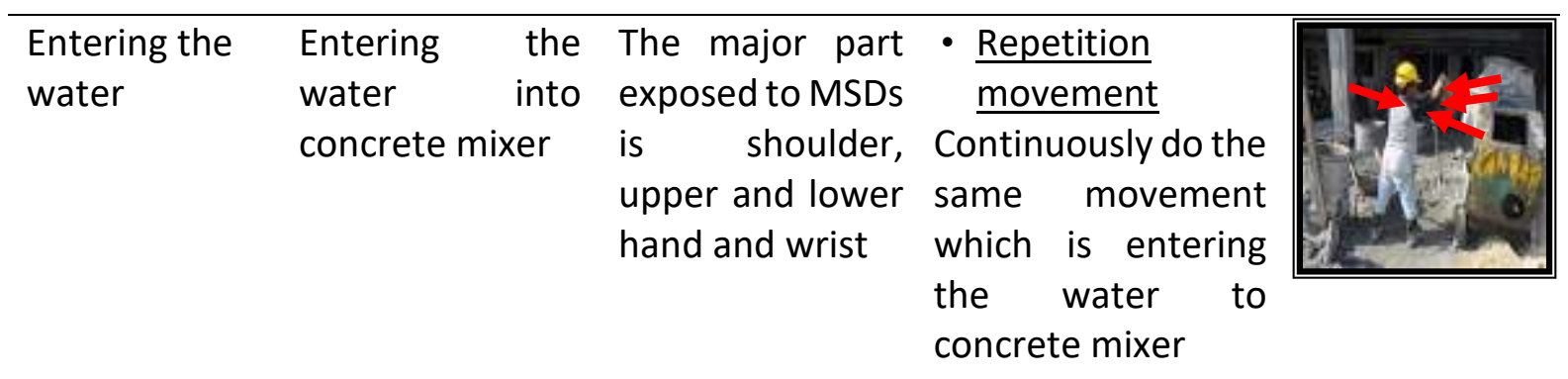

\begin{tabular}{|c|c|c|}
\hline $\begin{array}{l}\text { Operated the } \\
\text { concrete } \\
\text { mixer }\end{array}$ & 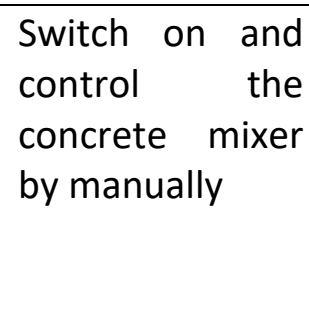 & $\begin{array}{l}\text { The major part }-\frac{\text { Physical contact }}{\text { stress }} \\
\text { exposed to MSDs } \\
\text { is shoulder, }-\frac{\text { Vibration }}{\text { upper and lower Rotating the roller }} \\
\text { hand, wrist, and of concrete mixer } \\
\text { knee. }\end{array}$ \\
\hline
\end{tabular}

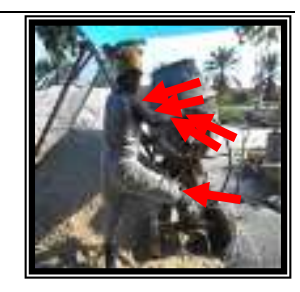

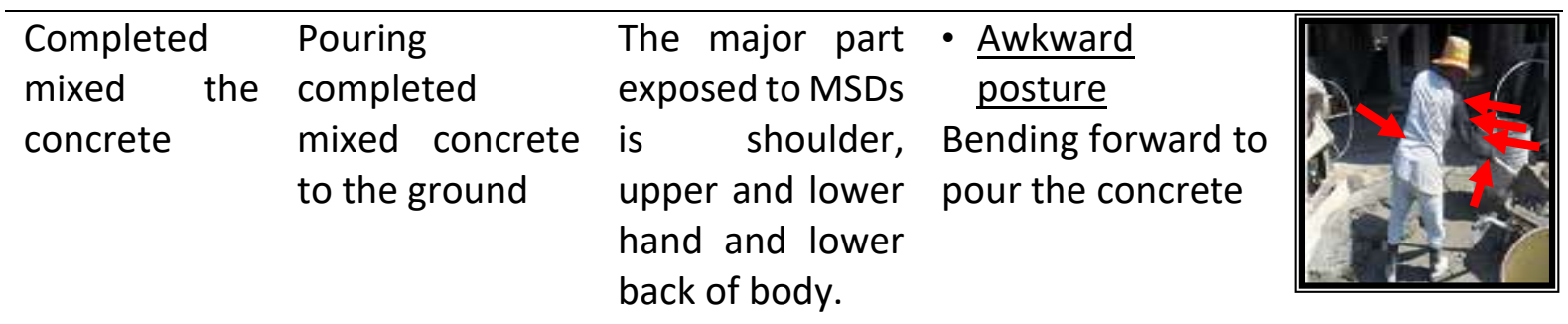

\begin{tabular}{|c|c|c|c|c|}
\hline \multicolumn{5}{|c|}{ TABLE 3. Continue } \\
\hline Activities & $\begin{array}{l}\text { Description of } \\
\text { Task/Activities }\end{array}$ & $\begin{array}{c}\text { Problematic } \\
\text { Work-Related } \\
\text { Activities } \\
\end{array}$ & $\begin{array}{l}\text { Ergonomic Risk } \\
\text { Factors (ERFs) }\end{array}$ & Figure \\
\hline $\begin{array}{l}\text { Transport the } \\
\text { fresh } \\
\text { concrete to } \\
\text { the location }\end{array}$ & $\begin{array}{l}\text { Transport the } \\
\text { fresh concrete to } \\
\text { the location } \\
\text { using } \\
\text { wheelbarrow }\end{array}$ & $\begin{array}{l}\text { The major part } \\
\text { exposed to } \\
\text { MSDs is } \\
\text { shoulder, upper } \\
\text { and lower hand } \\
\text { and wrist }\end{array}$ & $\begin{array}{l}\text { - } \text { Physical contact } \\
\text { stress } \\
\text { Working with } \\
\text { forearms and } \\
\text { wrists against the } \\
\text { wheelbarrow }\end{array}$ & \\
\hline
\end{tabular}

\begin{tabular}{|c|c|c|c|}
\hline $\begin{array}{l}\text { Pouring } \\
\text { concrete }\end{array}$ & $\begin{array}{l}\text { Pouring the } \\
\text { concrete to the } \\
\text { required area }\end{array}$ & $\begin{array}{l}\text { The major part } \\
\text { exposed to } \\
\text { MSDs } \\
\text { shoulder, upper }\end{array}$ & - $\frac{\text { Awkward }}{\text { posture }}$ \\
\hline
\end{tabular}


and lower hand, Bending forward

wrist and lower to pour the

back of body concrete

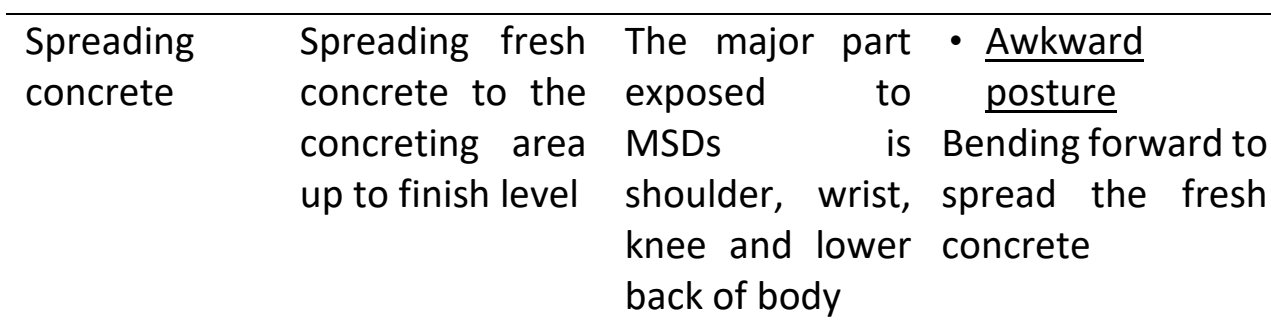

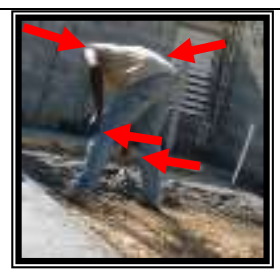

back of body

\begin{tabular}{|c|c|c|c|c|}
\hline $\begin{array}{l}\text { Vibrating } \\
\text { concrete }\end{array}$ & $\begin{array}{l}\text { Vibrating the } \\
\text { concrete to } \\
\text { minimize the } \\
\text { surface void at } \\
\text { the concrete }\end{array}$ & $\begin{array}{l}\text { The major part } \\
\text { exposed to } \\
\text { MSDs is } \\
\text { shoulder, lower } \\
\text { hand, wrist and } \\
\text { upper back of } \\
\text { body }\end{array}$ & $\begin{array}{l}\text { - } \frac{\text { Awkward }}{\text { posture }} \\
\text { - Vibration } \\
\text { Bending forward } \\
\text { to vibrate the } \\
\text { concrete by using } \\
\text { vibrator }\end{array}$ & \\
\hline
\end{tabular}

\begin{tabular}{|c|c|c|c|c|}
\hline $\begin{array}{l}\text { Trowelling } \\
\text { concrete }\end{array}$ & $\begin{array}{l}\text { Level the } \\
\text { concrete surface } \\
\text { using a steel or } \\
\text { timber trowel }\end{array}$ & $\begin{array}{l}\text { The major part } \\
\text { exposed to } \\
\text { MSDs is } \\
\text { shoulder, lower } \\
\text { hand, wrist, } \\
\text { knee and upper } \\
\text { back of body }\end{array}$ & $\begin{array}{l}\text { - } \frac{\text { Awkward }}{\text { posture }} \\
\text { Bending forward to } \\
\text { finish the concrete } \\
\text { by using timber } \\
\text { trowel }\end{array}$ & \\
\hline
\end{tabular}

\begin{tabular}{ll}
\hline Finishing & The major part \\
concrete & concrete for a exposed to posture \\
final surface of & MSDs to is Bending forward to \\
concrete & shoulder, lower final finish of the \\
& hand, wrist, concrete \\
& knee and lower \\
& back of body
\end{tabular}

\begin{tabular}{|c|c|c|c|c|}
\hline $\begin{array}{l}\text { Curing } \\
\text { concrete }\end{array}$ & $\begin{array}{l}\text { Keep the } \\
\text { concrete surface } \\
\text { in moisture to } \\
\text { build up strength } \\
\text { of concrete }\end{array}$ & $\begin{array}{l}\text { The major part } \\
\text { exposed to } \\
\text { MSDs is } \\
\text { shoulder, lower } \\
\text { hand, wrist and }\end{array}$ & $\begin{array}{l}\text { - Awkward } \\
\text { posture } \\
\text { Bending forward to } \\
\text { place the plastic } \\
\text { (material use for }\end{array}$ & \\
\hline
\end{tabular}




$\begin{aligned} & \text { lower back of } \begin{array}{l}\text { curing the } \\ \text { concrete) on the } \\ \text { body }\end{array} \\ & \text { concrete surface }\end{aligned}$

Musculoskeletal disorder if not controlled and properly handled, it will affect the longterm to the muscle and tend to get muscle injury. Therefore, prevention and control measures on the site activities particularly on brickwork are important to make sure that sign of musculoskeletal disorder to the workers can be reduce. Prevention and control measures involve a systematic approach between the worker and the tasks, tools, equipment and environment of construction. Workers and contractors alike must see some advantage to making changes to these elements of work system in order for measures to reduce the muscle injuries. For example, a substantial reduction in the physical work from the adjustment of working height by providing scaffolding is needed. By using a lifting machine to transport the cement bag from store are to the area of mixing concrete. It can avoid the continuous bending forward and downward while lifting the cement the scaffolding. The frequencies of bend forward and downward of the body by the concreters can cause the body exposed to MSDs for instance; shoulder disorder, upper and lower hand disorders, wrist disorder, knee disorder and upper and lower back disorders.

\section{Conclusion}

This paper concludes that there are some activities or tasks of concreter that affects the body's muscle discomfort that influenced by ergonomics risk factors. It is due to repetition movement, awkward posture, forceful exertion, vibration and contact stress. However, based on the observation, awkward posture is among the factors contribute to the higher ergonomic risk that affects the body muscles. The affected body muscles are shoulders, upper back, lower back, hands, wrists, thighs and knees. Muscles that are affected over a long period of time will result to the musculoskeletal disorder and simultaneously led to the musculoskeletal injuries. Future research in this area should document the self-reporting musculoskeletal disorder or injuries and to identify the level of pain experienced by the concreters.

\section{Corresponding Author}

Corresponding Author: Nor Suzila Lop

E-mail: norsu993@.uitm.edu.my

\section{References}

AH Tharim, A. H., Jaffar, N., Lop, N. S., \& Kamar, M. I. F. (2011). Ergonimic risk control in construction industry: A literature Review. Proceedia Engineering, vol. 20, 80-88.

DOSH (2016). Statistic Report of Occupational accidents for the category of death until October 2016. Department of Occupational Safety and Health, Malaysia.

Jaffar, N., Tharim, M. A. H., Kamar, M. I. F., \& Lop, N. S. (2011). A Literature Review of Ergonomics Risk Factors in Construction Industry. Proceedia Engineering, vol. 20, 89-97.

Lop, N. S., Kamar, I. F. M., Aziz, M. N. A., Abdullah, L., \& Akhir, N. M. (2017). Work-related to musculoskeletal disorder amongst Malaysian construction trade workers: bricklayers. AIP Conference proceedings 1891 (1), 020087. 
Matarid, N. M., Sobh, O. S., \& Ahmed, U. (2018). The Impact of Organizational Justice and Demographics on Faculty Retention in Bahrain. Le travail humain, (3).

Sangakala, M., Ahmed, U., \& Pahi, M. H. (2016). Empirical investigating on the role of supervisor support, job clarity, employee training and performance appraisal in addressing job satisfaction of nurses. International Business Management, 10(23), 5481-5486.

Santos, A., Ramos, H. M., Ramasamy, G., \& Fernandes, C. (2014). Improving Workers Health in Projects Based Work: Job Security Consideration. International Journal of Managing Projects in Business, vol 9, 606-623.

Schneider, S. \& Susi, P. (1994). Ergonomics and Construction: A review of potential hazards in new construction. American Industrial Hygiene Association Journal, vol. 55, 635-649.

Schneider, S. P. (2001). Musculoskeletal Injuries in Construction: A review of the Literature. Applied Occupational and Environmental Hygiene.

SOCSO (2016). Statistic report about the numbers of accidents by industry year 2016 Social Security Organization, Malaysia.

Te-Hsin, P. \& Kleiner, B. H. (2001). New developments concerning the occupational safety and health act. Journal of Managerial Law, vol. 43(1/2), 138-146. 